\title{
The Development of Character Education Management Model in Secondary School
}

\author{
Nurhayati, Sulasminten, Erny Roesminingsih \\ Post-Graduate, Universitas Negeri Surabaya \\ Surabaya, Indonesia \\ nurhayatinurhayati16070845007@mhs.unesa.ac.id
}

\begin{abstract}
Character education management is the integrated steps which include the process of planning, organizing, directing, and supervising conducted by the school as an attempt to implement the character values effectively and efficiently involving all stakeholders. Thi research aimed to describe and analyse the feasibility, practically, and effectiveness of the character education management model. The research used qualitative approach by combining facts and data to describe the condition of community character in the school. This research used research and development type and used the Four D model by Thiagarajan, define, design, develop, and disseminate. The research subjects were stakeholders in the secondary high school of Al Falah Assalam Tropodo, Sidoarjo. The data were collected from four techniques; they were an interview, observations, documentation, and test and non-test by using instruments in the form of expert validation sheets, questionnaire testing process guides and stakeholder response questionnaires. The results of development are five character building guides for principal, teacher, educational staff, student, and school committee of each element roles for character building, and there is also the example of student disciplinary assessments. In terms of practicality, it can be used easily while in terms of effectiveness, the content of the material is easy to understand and implement.
\end{abstract}

Keywords - character education; management of character education; guidelines of character building

\section{INTRODUCTION}

Indonesia is a very lucky country because of its natural resources such as natural gas, petroleum, gold, and other metals, coal and other minerals, marine, forest and biodiversity, plantation and agriculture are quite abundant. Indonesia also has a variety of ethnic groups with their respective cultural character, but on the other hand, the crisis of identity and pandemic of corruption has become a separate thought by the government Coordinating Ministry for Human Development and Culture, 2016 [1]

The high level of corruption and abuse of power by state officials and private parties suggests that our educational institutions have failed to instill the values of character in their graduates. The news about the characteristic behavior of junior high school students almost always adorns the newspaper news. This shows that the character's values have not penetrated in the mind and behavior of the students. The indicator shows that the level of implementation of the student's character values is very low.
The low quality of education is not only about cognitive factors, but also concerns aspects of the affective domain [2]. Looking at the student situation, the education of character of the educational unit is felt very urgent. To that end, the integration of character development into the curriculum and the learning process in schools should be given priority.

Character education functions: (1) builds a multicultural national life, (2) builds a smart, noble civilization, and is able to contribute to the development of human life, develops the basic potential to be kind, good-minded and well behaved and exemplary well, (3) builds the attitude of citizens who love peace, creative, independent, and are able to live side by side with other nations in harmony [3]

Teaching character education at school is as important as teaching academic problems [4] So, between academic education and character education must run parallel in school.

[5]state character education must be an integral part of an education system. In order for the implementation of character education in education/school units to run well, it is necessary to have character education management, thus each education/school unit is expected to have a character education management blueprint which is a reference for every school's stakeholders. [5]

The best way to implement character education is to integrate the content of character elements in hard skill tasks and characters in the curriculum and learning [6] According to Daniel Goleman that the success or success of a person in society, which is 80 percent influenced by emotional intelligence (EQ), and 20 percent by brain intelligence (IQ) [7]

Judging from the school and teachers, the application of the values of the characters in the school environment and learning process is also not maximal. Therefore, the researcher conducts research and development of a product for improvement of character education strengthening program which has been mandated in Presidential Regulation no. 87 of 2017 on Strengthening Character Education. This research is research development, or also called Research and Development (R\&D), wherein this research, the researcher produces the product in the form of character development guideline. 
The purpose of this research and development was to analyze and describe the feasibility, practicality, and effectiveness of the character education management model. While the limitations of the study, namely: lead to one element of the application of habituation, especially in the inculcation of the values of character to all school stakeholders, and the focus of research on the analysis and description of the feasibility, practicality, and effectiveness of character education management model.

Character education is a conscious and earnest effort by a person or group of people to instill the character values of another person in order to have behavior in accordance with the values held in a society.

The low character values of the community and the importance of character education, the President of the Republic of Indonesia has launched National Movement of Nation Character Development (Gerakan nasional Pembangunan Karakter Bangsa/GNPKB) at the peak of National Education Day on 2 May 2010, and encouraged the government to undertake a mental revolution program for all levels of society. To implement the National Movement of Nation Character Development (GNRM), in the field of education the government has issued Presidential Regulation no. 87 of 2017 on Strengthening Character Education[8]

Strengthening Character Education (Penguatan Pendidikan Karakter), here in after abbreviated as $P P K$, is the education movement under the responsibility of educational unit to strengthen the character of the students through the harmonization of spiritual and emotional, intellectual, physical and kinesthetic, affective and creativity with the involvement and cooperation between educational unit, family, and society as part of National Movement of the Mental Revolution (Gerakan Nasional revolusi Mental/GNRM).

Strengthening Character Education (Penguatan Pendidikan Karakter/PPK) has a purpose: (1) build and equip students as the gold generation of Indonesia in 2045 with Pancasila soul and good character education in order to face the dynamics of change in the future, (2) develop a national education platform that puts character education as the main spirit in the provision of education for students with the support of public engagement through formal, informal, and informal education with respect to Indonesian cultural diversity, and (3) revitalize and strengthen the potential and competence of educators, education personnel, students, communities and the family environment in implementing Strengthening Character Education (Presidential Regulation, article 2 no. 87 of 2017 on Strengthening Character Education).

Viewed from the psychological and social aspects of the culture within the individual, there are four functions of human potential that include: cognitive, affective, konatif, and psikomotorik capabilities (Kemendiknas, 2010). Such capabilities play a role in the context of cultural social interactions such as family, school, and community and last for life. Psychologically and socially culturally, these capabilities are grouped into Spiritual and emotional development (Olah Hati); Intelectual development (Olah Pikir); Physical and kinesthetic development (Olah Raga dan Kinestetik); Affective and creativity development (Olah Rasa and Karsa). The configuration of the scope of character education can be described as follows. [9]

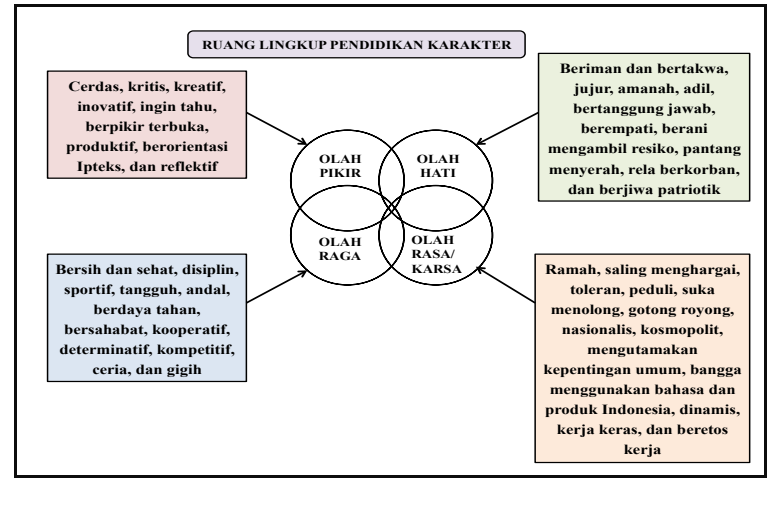

Picture 1

The scope of Character Education

(Source: Ministry of Education and Culture 2010)

Character education management is an integrated step that includes the process of planning, organizing, directing, and supervision conducted by the school to implement the character values effectively and efficiently, involving all school stakeholders. In order for the implementation of character education in educational units to run well, then the need for character education management, thus each educational unit is expected to have a blueprint for character education management that becomes a reference for every school's stakeholders.

In order to strengthen the implementation of character education management in educational units, 18 identified values originating from religion, Pancasila, culture, and national education objectives, (1) Religious, (2) Honest, (3) Tolerance, (4) Discipline, (5) Hard work, (6) Creative, (7) Self, (8) Democratic, (9) Curiosity, (10) Love of the homeland, (12) Respect for achievement, (13) Friendly/Communicative, (14) Love peace, (15) Love reading, (16) Caring for the environment, (17) Social care, (18) Responsibility (Source: Curriculum Center. Development and Education of Culture and Nation Character: School Guidance. 2009: 9-10/Pusat Kurikulum. Pengembangan dan Pendidikan Budaya dan Karakter Bangsa: Pedoman Sekolah. 2009: 9-10), so the development of the nation's character values can be described as follows. [10] 


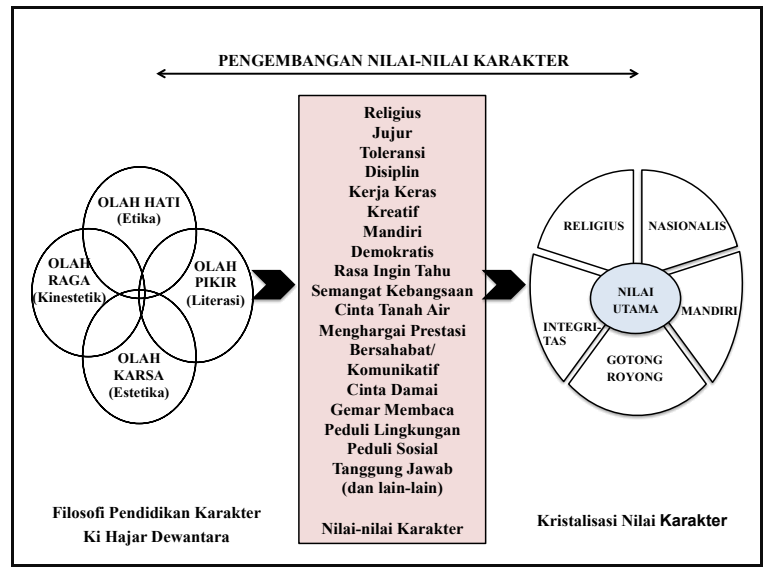

Picture 2 Development of Character Values

(Source: Curriculum Center Development and

Cultural Education and Nation Character:

School Guidelines, 2009: 9-10)

These character values are values inspired by the precepts of Pancasila, developed from the book Design Master Character Building 2010-2025, Government of Indonesia, 2010 (Desain Induk Pembangunan Karakter Bangsa 2010-2025, Pemerintah Republik Indonesia, 2010), presented as follows:

1. Character sourced from Intelectual development, such as: intelligent, creative, innovative, critical, analytical, curious, science-oriented, and reflective.

2. Character sourced from Spiritual and emotional development, such as honesty, trust, faithful and cautious, grateful, patient, orderly, fair, obedient rules, discipline, empathy, responsible, have compassion, never give up, appreciate the environment, willing to sacrifice, and spirited patriotic.

3. Character sourced from Physical and kinesthetic development, such as: clean and healthy, tough, sportive, cheerful, tenacious, persistent, reliable, friendly, resilient, cooperative, competitive, and determinative.

4. Characters sourced from affective and creativity development, such as humanity, mutual love, mutual respect, caring, togetherness, mutual cooperation, respectful, friendly, tolerant, prioritizing public interest, nationalist, cosmopolitan, dynamic, hard work, beretos work, proud to use the product and the Indonesian language.

Implementation and development of character values that will be developed and implemented in schools start from simple, essential, and easy-to-implement values, such as: clean, tidy, comfortable, disciplined, polite and courteous.

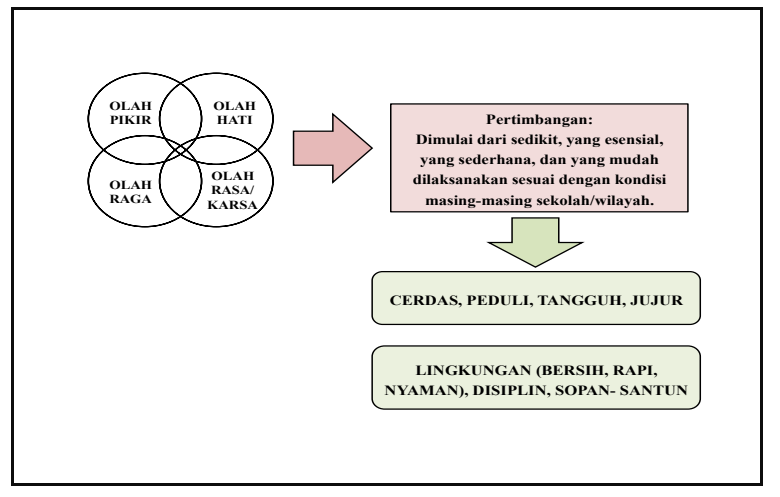

Picture 3 Implementation of Character Values (Character Education Implementation Guide, Center for Curriculum and Bookkeeping)

Character development guidance is the product of the development of a character education management model, where it provides information to enhance knowledge about character values, and guides /guides all elements of the school community, such as: principals, teachers, students, and committees in assisting the process/program of developing and implementing character values effectively and efficiently according to their respective roles to build character in accordance with the vision and mission of $\mathrm{Al}$ Falah Assalam Educational Institute, and there are examples in the guidelines on the assessment of school rules that will be used in student discipline assessment.

\section{METHOD}

This study used a qualitative approach by combining facts and data to describe the condition of community character in school. This research was research and development research which adapted from the Thiagarajan development model or called Four-D (4-D) method including define, design, development, and disseminates [11]

Research subjects were all elements of the school community such as principals, teachers, education personnel, students, and committees. The research was conducted in junior high school of Al Falah Assalam Tropodo, Waru Sidoarjo district. Data collection techniques used interviews, observation, documentation, instruments in the form of expert validation sheet, a questionnaire of guidance testing process, and questionnaire response of all elements of the school community [11]

Development Procedures

\section{Definition Step}

In this step consists of several steps, namely after the initial observation / preliminary study, can be defined as some requirements of development that is: (a). in addition, during this character education in schools is less applicable to the implementation of the values of the actual characters are still lacking; (b) the characteristics of the school stakeholders in Junior High School Al Falah Assalam Tropodo Sidoarjo require strengthening in the 
planting of character values, because the vision of the school is to realize the students noble and optimal achievement; (c) ask analysis is an understanding of the task in character development based on the role of each element of the school community such as principals, teachers, education personnel, students, and committees; (d) concept analysis contains an analysis of the character values that will be developed in the planting of character values. This analysis aims to make students better understand the values of character with a discipline and school order as the entrance to strengthening character education, so that it can be implemented in everyday life; (e) based on task analysis and concept analysis used as a reference for the preparation of guidance with the role of each school stakeholder in character development in school.

The purpose of the development is to produce products in the form of guidelines for all elements of the school community that will be used for monitoring the inculcation of character values and mentoring the implementation of government programs in strengthening character education in educational units independently and gradually, and test the feasibility, effectiveness and practicality of the product.

\section{Design Step}

At this step, (a) the researcher makes the pattern of character education management model in the form of the guideline, which refers to the requirements of a guideline that is the content feasibility, presentation, language and illustration in accordance with National Education Standards Board 2007 (Badan Standar nasional pendidikan/BSNP 2007), (b) selection of character education management model format, done by reviewing existing activities, then analyzed and adjusted with character education materials, so that the intended purpose can be achieved, (c) the initial design of a character education management model, contains a draft 1 that produces guidelines for a character education management model plan in the form of character development guidelines.

\section{Development Step}

The objectives at this step resulted in a draft model of character education management in the form of character development guidelines, which have been revised by reviewers. This stage consists of two steps, namely: (a) expert validation, in which the character development guideline prior to use must go through a validation stage aimed at improving the initial design of the device (draft 1 expert validation, in which the character development guideline prior to use must go through a validation stage aimed at improving the initial design of the device (draft 1), (b) validation is done by material experts and media experts, as well as lecturers who understand about the development of character.
After draft 1 was tested with all elements of the school community twice, namely: (a) limited trials are conducted to determine the implementation of the character development guidelines, understanding the content of the material, and so forth. Results from a limited trial are used as input, correction, and improvement to draft 2 and produce draft 3, (b) field trials are the implementation of character-oriented character development guidelines that will be applied. This trial is a further trial that applies to all elements of the real school community.

\section{Dissemination Step}

At this stage, the use of character education management models in the form of character development guidelines can be developed on a wider scale such as other junior secondary schools or in other educational units, especially primary and secondary education.

\section{Trial Design}

The product trial was conducted in two stages, ie trial 1 (small group trial) and trial 2 (field trial). Field test in this research using observation and interview and documentation because only use a qualitative approach, hence the effectiveness of the product before and after analyzed by descriptive.

\section{Test Subject}

The test subject in this development research is all elements of the school community in Junior High School Al Falah Assalam Tropodo Sidoarjo. Subject test 1 (small group test) is 1 principal, 3 teachers/ homerooms, 2 educational staffs, 5 students, and 2 committees. The trial subjects 2 (field trial) were 2 principals (primary and secondary), 10 teachers/ homerooms, 4 educational staffs, 25 students, and 3 committees.

\section{Data}

The data in this study consists of two types, namely: (1) primary data. This data is about the feasibility of the character education management model outlined in character development guidelines for character education materials. The data collected in the form of validation from experts and supervisors, as well as test results data, (2) secondary data. This data is obtained from field trial activities. These data include results of feasibility, practicality, and effectiveness of the analysis and description of character education management models in the form of guidelines for character development.

\section{Instrument}

The research instruments are interview, observation, documentation, expert validation observation sheet, a questionnaire of guidance testing process, and questionnaire 
response all elements of the school community, which first tested the validity and reliability.

Data Analysis Technique

Data management in this study used qualitative descriptive analysis which includes: feasibility analysis, practicality, and effectiveness, the response of all elements of the school community in the implementation of strengthening character education in schools. The feasibility, practicality, and effectiveness analysis, as well as the response of all elements of the school community, are observed before and after the guidance of character development to know the quality of the outcome of the development of the character education management model.

Assessment of the implementation of character development guideline is performed by validators who are experts in the field, so as to judge with objective observation/validation sheets. Assessment of the implementation of character development guideline is performed by validators who are experts in the field, so as to judge with objective observation/validation sheets.

\section{RESULTS AND DISCUSSION}

The final result of this research and development is in the form of five character development guidance as a guide to increase knowledge about character. These guidelines are used by all elements of the school community such as principals, teachers, education personnel, students, and committees with their respective roles in strengthening character education programs in schools, and there are also examples of student disciplinary assessments to be used in student discipline assessment.

The results have supported the theory of Lickona [12] there are three components in character education, namely: moral knowing, good feeling or moral feeling and moral action so that the realization of the unity of behavior and attitude of life is formed, learners. These also emphasis by Samani and Hariyanto (2011, p. 50) state that moral action can realize the unity of behavior. [13]

This development research is a character education management model developed using Four-D Thiagarajan method which has been implemented into three stages. Stages of development research consist of defining, designing, and developing.

The defining phase is done through observation either directly or indirectly about the condition of character in SMP Al Falah Assalam Tropodo Sidoarjo, know the characteristics of all elements of the school community, as well as develop guidelines with the role of each element of the school community in strengthening character education programs in schools.

The design step contains the stages to develop a character education management model whose outcome is a guideline of character development for all elements of the school community to improve knowledge about the character that will be used for strengthening character education in schools as a mandate from the government based on Presidential Regulation no. 87 of 2017 on Strengthening Character Education.

In the development step, the results of development include (1) Validation of material experts conducted by prof. Dr. Muchlas Samani, M.Pd who is a material expert of character, (2) validation of media experts conducted by prof. Dr. Mustaji, M.Pd who is a product design expert, (3) validation of supervisor by Dr. Sulasminten, M.Pd, and lecturer 2 by prof. Dr. M. V. Roesminingsih, M.Pd. (4) the response of all elements of junior high school community $\mathrm{Al}$ Falah Assalam Tropodo Sidoarjo, (4) small group trials conducted at SMP Al Falah Assalam Tropodo Sidoarjo, (5) field trials conducted at SMP Al Falah Assalam Tropodo Sidoarjo, then than through observations before and after the implementation of product trials in the form of character development guidelines.

\section{CONCLUSION}

Based on the results of data analysis and discussion, it can be concluded that the character education management model in this study is developed using Four-D model from Thiagarajan and implemented into three steps. The steps consist of define, design, and develop.

Define functions to seek the needs in the process of observing the character conditions on all elements of the school community. In this stage, there are five steps, namely: pre-research, student analysis, concept analysis, task analysis, and product formulation. Design is the selection of the format and initial design of products to be made and at the stage of the development of validation of material/content and media which will be used in strengthening the character education program in schools.

The product of the development of a character education management model in the form of guidelines for character development for all elements of the school community such as: principals, teachers, education personnel, students, and the committee after obtaining an assessment of expert validation, material and media experts, as well as lecturers expressed feasible to be implemented in the program of strengthening character education at SMP Al Falah Assalam Tropodo Sidoarjo.

The description of the assessment can be seen as follows: (1) material experts assess the feasibility aspects of content and linguistic aspects, (2) media experts judge from aspects of presentation and systematics. Assessment of the supervisor is given on aspects of objective formulation, material selection, content feasibility aspects, language, and aspects of presentation, and systematics. Aside from the assessment of the experts, this character education management model development product has been tested in small groups and field trials. 
The results of the test show that the product is feasible to be used, proved by the observation that the increase of knowledge about the character and the implementation of discipline in every activity after using the character education management model in the form of character development guidance, more visible and felt in junior high school Al falah Assalam Tropodo Sidoarjo.

\section{SUGGESTION}

Character education management model in the form of character development guideline is expected to be used as an example in the program of strengthening character education in educational unit, especially primary and secondary education. Products in the form of character development guidelines can be further developed with additional materials that are linked to all subjects.

\section{REFERENCE}

[1] K. K. B. P. M. D. Kebudayaan, Gerakan Nasional Revolusi Mental. Jakarta: Menko Bidang Pembangunan Manusia Dan Kebudayaan. 2016.

[2] Tribunnews.com, "Begini Kronologi Duel Gladiator Siswa SMA, Janji Bertarung, Kejang-Kejang Lalu Tewas," Selasa 26 September 2017., Bogor, 2017.

[3] K. Benninga, JS., Berkowitz, MW., Kuenh, P and Smith, "The Relationship of Character Education Implementation and Academic Acheivement in Elementary School," J. Res. Character Educ., p. 1932., 2003.

[4] T. Gray, "Character Education in School.," ESSAI Vol 7, Artic. 21, vol. 7, p. 21, 2009.

[5] D. K. Narvaez, D and Lapsley, Teaching Moral Character: Two Strategy for Teacher Education. In Pres, Teacher Educator: Center for Ethical Education University of Notre Dame., 2007.

[6] M. Berkowitz, MW., and Bier, "What Works In Character Education: A reserach -driven guide for educators," 2005.

[7] Rohman, Kurikulum Berkarakter. Jakarta: Prestasi Pustakaraya, 2012.

[8] L. N. R. I. T. 2017 N. 195, "Peraturan Presiden Republik Indonesia Nomor 87 Tahun 2017 Tentang Penguatan Pendidikan Karakter," 2017.

[9] Kemdiknas, Desain Induk Pendidikan Karakter. Jakarta, 2010.

[10] S. Guidance, "Pusat Kurikulum. Pengembangan dan Pendidikan Budaya dan Karakter Bangsa," 2009.

[11] Sugiyono, Metode Penelitian dan Pengembangan (Research and Development). Bandung: Alfabeta, 2017.

[12] Megawangi, Pendidikan Karakter. Indonesia Heritage Foundation, 2004.

[13] M. . Samani dan Hariyanto, Konsep dan Model Pendidikan Karakter. Bandung: Remaja Rosdakarya, 2013. 